\title{
Mild form of inverse Klippel-Trenaunay syndrome?
}

\author{
Gustavo Queirós, ${ }^{1}$ Filipa Diamantino, ${ }^{2}$ Maria João Lopes ${ }^{2}$
}

${ }^{1}$ Medical Pediatrics, Hospital Dona Estefânia, Lisboa, Portugal

${ }^{2}$ Dermatology Service, Hospital Santo Antonio dos Capuchos, Lisboa, Portugal

\section{Correspondence to} Dr Gustavo Queirós, gusta1983@gmail.com
To cite: Queirós $\mathrm{G}$, Diamantino F, Lopes MJ. BMJ Case Rep Published online: [please include Day Month Year] doi:10.1136/ bcr-2013-009188

\section{DESCRIPTION}

Klippel-Trenaunay syndrome (KTS) is defined by a coexistence of nevus flammeus and overgrowth of one or more limbs. Remarkably, however, deficient growth of an affected limb may likewise be noted. It has been speculated that either a 'plus' or 'minus' allele at the responsible gene locus in the postzygotic cells might be involved in the occurrence of overgrowth or underdevelopment of the affected limb, respectively. ${ }^{1}$

Orthopaedic complications are related to limb asymmetry and bone hypertrophy. Arteriovenous malformations may lead to thromboembolic events or high-output cardiac failure. ${ }^{2}$

A 5-year-old boy was referred to the dermatology clinic for evaluation of a congenital port-wine strain in the right buttock. He was otherwise healthy, apart from past surgery for cleft palate correction.

On examination we observed a telangiectatic nevus with focal dermal and soft tissue atrophy in the right buttock (figures 1 and 2). There was no significant difference in limb length or circumference.

MRI excluded major organ or vascular abnormalities.

In principle, a pre-requisite of KTS is partial or complete overgrowth of a limb. However, there are also patients with shortening or smaller muscle mass of the affected limb. This fact lead to the recently proposed concept of 'inverse Klippel-Trenaunay syndrome'. ${ }^{13}$ This case may be included in the mildest spectrum of this clinical condition.

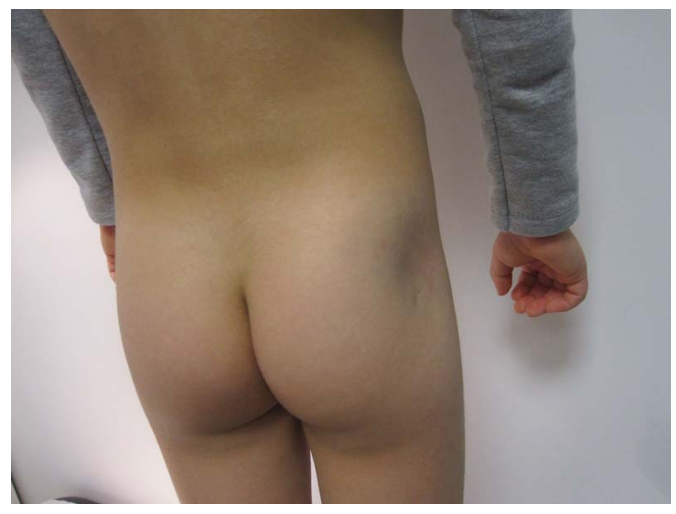

Figure 1 Focal dermal and soft tissue atrophy.

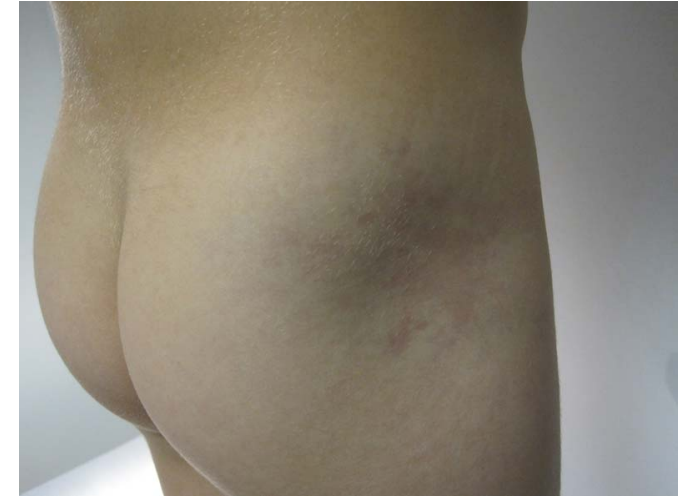

Figure 2 Telangiectatic nevus.

\section{Learning points}

- The association between port-wine nevus and soft tissue/limb hypotrophy or hypertrophy should recall the Klippel-Trenaunay syndrome (KTS) spectrum.

- A child with KTS requires limb growth monitoring in order to prevent orthopaedic complications.

- When feasible and clinically relevant, imaging studies may be helpful in excluding major vascular abnormalities.

Competing interests None.

Patient consent Obtained.

Provenance and peer review Not commissioned; externally pee reviewed.

\section{REFERENCES}

1 Danarti R, König A, Bittar M, et al. Inverse Klippel-Trenaunay syndrome: review of cases showing deficient growth. Dermatology 2007:214:130-2

2 Mendiratta V, Koranne RV, Sardana K, et al. Klippel Trenaunay Parkes-Weber syndrome. Indian I Dermatol Venereol Leprol 2004:70:119-22.

3 Cappuccio G, Brunetti-Pierri N. Focal congenital lipoatrophy and vascular malformation: a mild form of inverse Klippel-Trenaunay syndrome? Eur J Med Genet 2012;55:705-7. 
Copyright 2013 BMJ Publishing Group. All rights reserved. For permission to reuse any of this content visit http://group.bmj.com/group/rights-licensing/permissions.

BMJ Case Report Fellows may re-use this article for personal use and teaching without any further permission.

Become a Fellow of BMJ Case Reports today and you can:

- Submit as many cases as you like

- Enjoy fast sympathetic peer review and rapid publication of accepted articles

- Access all the published articles

- Re-use any of the published material for personal use and teaching without further permission

For information on Institutional Fellowships contact consortiasales@bmjgroup.com

Visit casereports.bmj.com for more articles like this and to become a Fellow 